\title{
Separating the wheat from the chaff
}

\section{Topic: Archaeobotany}

Biological sciences / Evolution / Archaeology

[URI /631/181/27]

Biological sciences / Plant sciences / Plant domestication

[URI /631/449/2492]

Bread wheat, so-called because of its springy gluten protein that allows dough to rise, accounts for around $90 \%$ of global wheat production today. This situation presents a striking contrast to ancient cuisines based on subsistence farming, which incorporated a diverse range of foods including staple grains.

What we now value as agrobiodiversity was inherent to the early systems of crop growing and stock raising that emerged in many regions around the world, and by 10,000 years ago in the Middle East. A case in point is the Neolithic site of Çatalhöyük (c. 7100-6000 BC) in the Konya plain of Anatolia, south-central Turkey (Fig. 1). This large, pueblo-like settlement extended over more than 13 ha in the mid$7^{\text {th }}$ millennium BC and was home to thousands of people. Alongside foraging, hunting, fishing, fowling and a range of craft activities, the inhabitants of Çatalhöyük cultivated crops ${ }^{1}$. Ancient wheat from Çatalhöyük is the subject of an archaeogenetic study recently published in PLOS ONE by Bilgic and colleagues ${ }^{2}$. But Çatalhöyük's patchwork landscape of small 'garden' plots was very different from the rippling swathes of perfectly uniform wheat fields that surround the site today. Farming at Neolithic Çatalhöyük created a complex and colourful mosaic, of grey and gold barleys and wheats, of green and yellow peas, lentils and wild mustard, and the blossoms and ripening fruits of almond, pistachio and hackberry.

Within this swirl of colours, tastes and ecologies, the Neolithic counterpart to today's bread wheat, Triticum aestivum L., was one of the crops grown at Çatalhöyük. Charring preserved wheat grains at the site, enabling Bilgic et al. to sequence fragmented DNA at loci that encode high molecular weight (HMW) glutenin protein, a component of gluten. This identifies the presence of hexaploid wheat, resembling either today's bread wheat, or the hulled wheat spelt. The authors report these results as the earliest wheat yet sequenced, and the first from the Middle East.

The work by Bilgic et al. belongs to the field of archaeogenetics, while morphological study of early crops falls within another subdiscipline: archaeobotany (or palaeoethnobotany). Archaeobotanists rely on the taxonomically distinctive morphology of surviving crop remains to identify (sub)species and varieties; in Turkey and across the Middle East, crop remains are typically grains and other dense plant parts ('chaff') preserved by charring, accidentally in domestic hearths or, more spectacularly, in the destruction of buildings by fire (Fig. 1). Experimental charring has shown that perfectly intact morphology in wheat grains occurs through heating to $c .220-240^{\circ} \mathrm{C}$; at higher temperatures, grains become distorted and hence difficult to identify to species ${ }^{3}$. More readily identifiable is preserved cereal 'chaff', such as the rachis, or stem within the cereal ear. Well preserved bread wheat rachises are 
thus distinguishable from those of the other naked or free-threshing wheat, tetraploid durum wheat (Triticum durum L.), as well as from those of spelt and other hulled wheats (Fig. 2).

As rachises, bread wheat is widely attested at Çatalhöyük throughout its thousandyear occupation (Fig. 2), while (hexaploid) spelt is unknown ${ }^{1}$. The findings of Bilgic et al. thus support bread wheat's occurrence, already well established by archaeobotany. These results also serve to highlight key questions: when/where did bread wheat first emerge, and when/where did it take on a special significance as a culinary staple, in preference to other (e.g. hulled) wheats and barley, for example? Bread wheat arose from the hybridization of domesticated tetraploid emmer (a hulled wheat) with diploid Aegilops tauschii Coss., a wild grass. This hybridization could have occurred at multiple locations within the overlapping distribution zones of early emmer cultivation and $A$. tauschii. Genetic analysis of modern bread wheat and $A$. tauschii land races suggests that present-day bread wheat has at least two separate origins, one in Turkey or northern Syria and the other in Iran ${ }^{4}$.

The rachis morphology of the earliest free-threshing wheats in the Middle East needs to be reviewed in order to disentangle the emergence of tetraploid and hexaploid naked forms. Nevertheless, it is clear that by the seventh millennium BC bread wheat was established not only in central Anatolia and elsewhere in the Middle East; it was spreading east and west, and had already gained a foothold in Europe, at early Neolithic Knossos on Crete $^{5}$. Naked wheat of a hexaploid and/or tetraploid type is sporadically attested in Neolithic Greece and the Balkans, eventually spreading across southern, central and northern Europe ${ }^{6}$.

Bread wheat is nowadays regarded as a more demanding crop than other cereals, but in part this reflects adaptation to favourable conditions allocated on the basis of culinary preference. Traditional bread wheat landraces, such as the ble meunier $d^{\prime} A p t$ in Haute Provence, France, can be adapted to low nutrient conditions. Perhaps our earliest direct indications of a special ecological and culinary status of naked (bread and/or durum) wheat is provided by stable carbon and nitrogen isotope analysis of ancient grains, from which we can infer the availability of water and organic matter, respectively, to crops during the growing season.

At the sixth millennium BC site of Kouphovouno, near Sparta, recent stable isotope analysis of naked wheat grains indicates that this crop was grown under more heavily manured conditions than barley ${ }^{7}$, and similar results have recently been obtained for Sipplingen, an early third-to-fourth millennium BC lakeshore settlement on Lake Constance in south-west Germany ${ }^{8}$. The same study also investigated nearby Hornstaad-Hörnle $1 \mathrm{~A}$, where a Neolithic lakeshore village burned down in 3909 BC, preserving stored crops in each house. Naked wheat in different houses had been produced with variable levels of manuring, and was used to make milled foods such as porridge and bread, whereas barley grains were roasted whole; both crops were consumed alongside a diverse range of resources. Fast-forward to AngloSaxon southern Britain, where texts suggest that bread wheat was a distinctly higher status crop than barley. Recent archaeobotanical investigation shows not only that 
barley and bread wheat were equally common, but also that they formed part of a diverse crop suite ${ }^{9}$.

Much work remains to be done on the ecological and culinary status of bread wheat at Çatalhöyük and beyond, but one key aspect is clear: this ancient wheat emerged as only one of a diverse spectrum of crops, and remained so for thousands of years. Then, as now, a sustainable and healthy future depends on the wisdom of having 'a little of everything' ${ }^{10}$.

Amy Bogaard is at the School of Archaeology, University of Oxford, Oxford OX1 2PG, UK. amy.bogaard@arch.ox.ac.uk

\section{References}

1. Bogaard et al. In Hodder, I. (ed) Humans and Landscapes of Çatalhöyük: Reports from the 2000-2008 seasons. (Monographs of the Cotsen Institute of Archaeology, University of California at Los Angeles, 2013).

2. Bilgic, H. et al. PLOS ONE 11, E0151974 (2016).

3. Charles, M. et al. STAR 1, 1-6 (2015).

4. Giles, R.J. and Brown, T.A. Theor Appl Genet. DOI 10.1007/s00122-006-0259-5

5. Sarpaki, A. In The Neolithic Settlement of Knossos in Crete: New Evidence for the Early Occupation of Crete and the Aegean Islands (eds Efstratiou, N. Karetsou, A. \& Ntinou, M.) 63-94 (INSTAP Academic Press 2013).

6. S. Colledge and J. Conolly (eds) The Origins and Spread of Domestic Plant in Southwest Asia and Europe (Left Coast Press, 2007).

7. Vaiglova, P. et al. J.Arch. Sci. 42, 201-215 (2014).

8. Styring, A. et al. Antiquity 90, 95-110 (2016).

9. McKerracher, M. Environmental Archaeology 21, 88-102 (2016).

10. Forbes, H. 1976. 'We have a little of everything': the ecological basis of some agricultural practices in Methana, Trizinia. Annals of the New York Academy of Sciences 268: 236-250.

Fig 1a (top) Reconstruction drawing of Çatalhöyük's immediate landscape, looking southwest, based on recent geoarchaeological and archaeobotanical analysis (illustration by Katy Killackey, copyright Çatalhöyük Research Project). 1b (bottom) A burned building (Building 52) at Çatalhöyük (photograph by Jason Quinlan, copyright Çatalhöyük Research Project).

Fig 2a (top). Schematic representation of the structure and processing stages of hulled and free-threshing (naked) wheat (illustration by Katy Killackey, copyright Çatalhöyük Research Project). 2b (bottom) Drawing of charred fragments of wheat 
rachis resembling hexaploid Triticum aestivum from Çatalhöyük (illustration by Katy Killackey, copyright Çatalhöyük Research Project). 